\title{
MYOFASCIAL PAIN SYNDROME
}

\author{
Shahdevi Nandar Kurniawan ${ }^{1}$, Nidia Suriani ${ }^{1}$, Eko Arisetijono Marhaendraputro ${ }^{1}$, Dessika Rahmawati ${ }^{1}$ \\ ${ }^{I}$ Neurology Department, Medical Faculty, Brawijaya University, Saiful Anwar General Hospital, Malang, Indonesia. \\ Correspondence : shahdevinandar@ub.ac.id
}

\begin{abstract}
Pain is a sensory experience that is responded to as an unpleasant stimulus that is often caused by tissue damage. Perdossi defines pain as an unpleasant sensory and emotional experience due to tissue damage, both actual and potential, or which is described in the form of such damage. Pain can affect everyone regardless of sex, age, race, social status, and occupation. Myofascial pain syndrome (MPS) is a term used to describe the condition of acute or chronic pain in musculoskeletal soft tissue. This is indicated by the findings of sensory, motoric, and autonomic symptoms related to myofascial trigger points (MTRP). The symptoms can be local or far from MTRP. In MPS that are far from MTRP, the pain patterns that appear are usually pain is pervasive The most common location for MPS is the neck and back. The purpose of writing this literature review is to explain epidemiology, clinical manifestations, pathogenesis mechanisms, pathophysiology mechanisms, and management in patients with myofascial pain syndrome. Myofascial pain syndrome is a pain syndrome in muscles that includes musculoskeletal abnormalities and MPS management shows that most interventions, both medical therapy and non-medical therapy, still need studies to prove its effectiveness.
\end{abstract}

Keywords : Myofascial Pain Syndrome, Myofascial triger points, management of myofascial pain syndrome.

\section{PENDAHULUAN}

Sindrom nyeri miofasial (MPS) didefinisikan sebagai nyeri yang berasal dari otot dan nyeri tersebut berasal titik tertentu yang terasa sangat nyeri pada otot tersebut. Titik yang sangat nyeri tersebut disebut juga dengan Myofascial Trigger Point (MTRP). MPS memiliki ciri-ciri berupa munculnya gejala motorik dan gejala sensorik, juga didapatkan gejala otonom, namun gejala otonom pada MTRP tidak terlalu penting dalam identifikasi klinis. Gejala penting yang harus didapatkan dalam diagnosis MPS adalah dalam proses menemukan MTRP yaitu membedakan MPS dari nyeri otot jenis lain. Perbedaan antara MPS dengan nyeri otot lain terletak pada adanya serabut otot yang tegang dengan nyeri tekan pada MTRP (1)

\section{MANIFESTASI KLINIS}

Tanda fisik atau motorik yang didapatkan dari MTRP adalah ditemukannya serabut otot yang kencang. Serabut otot ini merupakan kumpulan dari serat otot yang berkontraksi, serat otot ini terhubung antara satu ujung otot dengan ujung otot yang lain. Namun kaitan antar serabut otot ini tidak didapatkan dalam otot-otot di mana ada segmentasi anatomi otot, seperti pada kepala otot semitendinosus dari hamstring. Otot semitendinosus memiliki tendinous inscription pada bagian proksimal yang membagi otot menjadi dua hingga tiga bagian. Serat otot yang tegang ini, tidak dipengaruhi oleh aktivitas neuron motorik. Hal tersebut berdasarkan temuan klinis bahwa pada serat otot yang tegang tersebut tidak menunjukkan adanya aktivitas aksi potensial. Dimana aksi potensial umumnya ditemukan pada kontraksi otot. Kelainan lain yang muncul yang diduga berperan pada patofisiologis MTRP adalah munculnya respon kedutan local (local twitch response (LTR). LTR adalah kontraksi tajam dari serabut otot yang kencang. Kontraksi tajam ini muncul pada serat otot yang berdekatan dengan serat otot kencang dan tidak didapatkan pada seluruh otot. Hal ini jelas berbeda pada kontraklsi otot yang didapatkan pada dengan refleks tendon. LTR merupakan refleks sumsum tulang belakang. LTR sendiri didahului oleh stimulus fisik yang tajam seperti menarik dari serat otot yang tegang dengan tangan atau pada saat menusukkan jarum pada daerah MTRP (1). Manifestasi sensorik dari MTRP adalah didapatkannya nyeri tekan. Nyeri tekan pada zona MTRP merupakan nyeri yang dirasakan memberat dengan didahului oleh pemberian stimulus (hipersensitivitas) atau respon nyeri terhadap stimulasi yang pada umumnya tidak menyakitkan (allodynia). Nyeri alih dapat muncul secara intrinsik setelah dilakukan stimulasi pada MTRP. Hal ini dikarenakan pada MPS nyeri lokal maupun nyeri alih seringkali muncul. Kelemahan yang terjadi biasanya diakibatkan oleh proses inhibisi kontraksi yang dicetuskan oleh nyeri otot yang juga disebabkan oleh pemendekan otot.

Article History:

Received: 9 Februari 2020; Accepted: 11 Februari 2020; Published: 1 Maret 2020

Cite As:

Kurniawan SN, Suriani N, Marhaedraputro EK, Rahmawati D. Myofascial pain syndrome. Journal of Pain, Vertigo and Headache; 2020.1:17-21 
Koordinasi otot juga mengalami gangguan, karena proses koordinasi otot dipengaruhi oleh adanya inhibisi refleks dari otot antagonis $(1,2)$.

\section{Sindroma Nyeri Regional dan General}

Berbeda dengan karakteristik nyeri pada fibromyalgia, MPS memiliki nyeri berupa sindrom nyeri regional. Bahkan pada awalnya, MPS merupakan sindroma nyeri yang berasal dari otot tunggal dan pada perkembangannya MPS dideskripsikan sebagai nyeri yang berasal dari otot tunggal atau daerah tertentu. Frozen shoulder merupakan salah satu bentuk dari MPS regional. Frozen shoulder juga dapat diakibatkan kerusakan struktural lain seperti robeknya otot rotator cuff. Mekanisme yang mendasari perubahan MPS regional menjadi MPS general adalah penyebaran TRP. Proses pertama yang mempengaruhi terjadinya penyebaran TRP adalah melalui rantai kinetik aksial yang diakibatkan oleh adanya disfungsi postural dan stres mekanik pada otot. Proses kedua yang berperan dalam penyebaran TRP adalah aktivasi TRP pada kelompok otot fungsional, di mana otot-otot yang bertindak sebagai agonis atau antagonis mengalami overload karena terjadi mechanical stress. Mechanical stress terjadi karena proses kompensasi dari otot-otot yang mengalami disfungsi dalam suatu unit otot fungsional $(1,2)$.

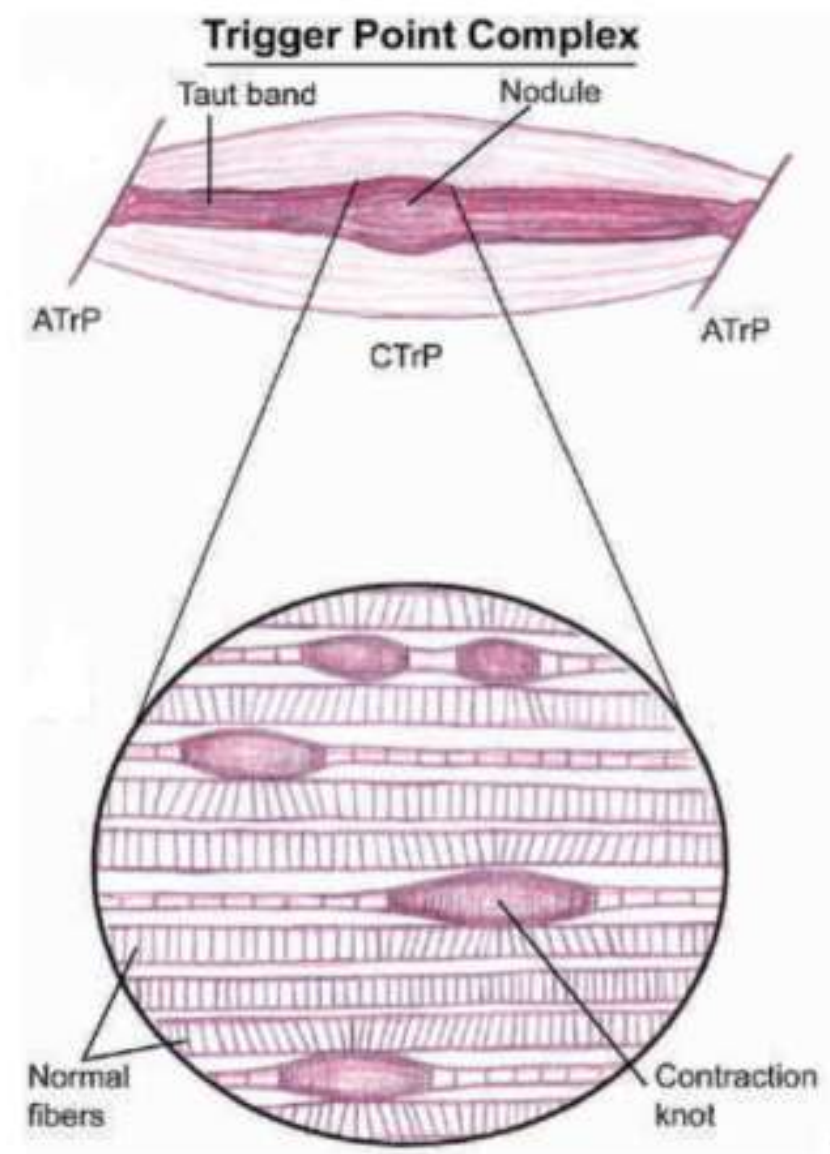

Gambar 1. Serat Otot yang tegang dan Local twitch Response (1)

\section{Sindroma Nyeri Myofascial Primer}

Nyeri kepala tipe tegang (tension type headache (TTH)) merupakan nyeri kepala kronis yang berasal dari faktor myogenic. TTH seringkali disertai dengan gejala seperti pada migren diantaranya mual dan peningkatan sensitivitas terhadap cahaya hingga fotofobia. Jenis sakit kepala dengan gambaran tersebut dapat dianggap nyeri kepala campuran TTH dan migrain. Seratus persen pasien dengan nyeri kepala campuran tersebut, sebagian besar menderita sakit kepala selama lebih dari 15 hari dalam sebulan dan memiliki MTRP aktif. Nyeri kepala sendiri dapat merupakan ekspresi rasa nyeri yang merupakan nyeri alih dari otot-otot leher dan bahu yang menyebar ke zona alih rasa nyeri di kepala $(1,2)$.

Otot-otot leher yang berkaitan dengan TRPS diantaranya adalah sternokleidomastoid, scalenes, levator skapula, trapezius, suboksipital dan otot leher posterior. Postural Stress adalah salah satu penyebab paling umum dari nyeri leher terkait TRP. Postur kepala ke arah depan dan bahu ke arah depan merupakan postur yang paling sering menyebabkan nyeri pada leher. Posterior displacement mandibula dapat mengakibatkan temporomandibular joint syndrome yaitu disfungsi sendi temporomandibular yang diikuti dengan nyeri kepala dan nyeri leher (2). Nyeri bahu juga dipicu oleh biomekanik tubuh yang buruk, terutama dalam gerakan rotasi eksternal dan rotasi internal pada bahu. Nyeri bahu dan terbatasnya gerakan bahu merupakan gejala yang umumnya didapatkan pada MTRP primer. Nyeri pinggul seringkali didiagnosis sebagai bursitis trokanterika terutama jika gambaran klinis yang diperoleh berupa nyeri pinggul lateral, sindrom nyeri pada saat penekukan lutut merupakan nyeri yang berasal dari TRPS pada otot vastus medialis, Nyeri Punggung bawah (NPB) merupakan gejala yang paling sering dikaitkan dengan adanya TRPS pada otot kuadratus lumborum dan seringkali diikuti adanya TRPS pada otot paraspinal superfisial, Sindrom piriformis merupakan kumpulan gejala yang mengakibatkan nyeri pada pantat dan nyeri pinggul. Gejala nyeri ini sendiri disebabkan oleh TRPS pada otot piriformis (2).

Tabel 1. Sindrom Nyeri Miofasial Primer (2)

- Nyeri kepala miogenik: tipe ketegangan kronis dan tipe campuran / sakit kepala migrain

- Nyeri leher

- Nyeri bahu

- Bahu beku

- Nyeri pungguug bawah

- Sindrom piriformis

- Nyeri lutut

- $\quad$ Nyeri pergelangan kaki

\section{Sindroma Nyeri Miofasial Sekunder}

Sindrom nyeri myofascial sekunder, merupakan MPS, dimana didapatkan kondisi medis lain yang berkaitan dengan munculnya MPS, Cervical Whiplash merupakan salah satu contoh penyakit yang mendasari MPS, juga disebabkan oleh migrain. Pada sindrom nyeri kepala kronis, mengetahui mekanisme TRPS berkontribusi pada munculnya nyeri kepala dan berkaitan dengan MPS sekunder hingga kini belum diketahui dan sulit dipahami $(1,2)$.

Disfungsi sendi temporomandibular (Temporomandibular joint (TMJ)) merupakan keadaan dengan gejala nyeri pada kepala dan leher TRP. Nyeri akibat disfungsi TMJ tersebut dapat diakibatkan secara langsung oleh TRPS namun dapat pula diakibatkan oleh nyeri alih ke dalam kepala dan leher 
Tabel 2. Sindrom Nyeri Miofasial Sekunder (2)

- Nyeri leher whiplash serviks kronis

- Disfungsi sendi temporomandibular

- Bahu beku sekunder: sindrom tubrukan, rotator cuff tear

- $\quad$ Sindrom nyeri visceral: nyeri dada nonanginal, nyeri hepatik, nyeri panggul ginjal / ureter

- Variasi anatomi struktural: skoliosis, torsi pelvis, ketidaksetaraan panjang kaki

- Nyeri radikuler

- Sindrom post-laminektomi

- Radang sendi

- Osteoartritis: spondylosis serviks dan lumbar, osteoartritis pinggul atau bahu

- Sindrom sjorgen

- Fibromyalgia

- Trauma akut: fraktur, cedera jaringan lunak, nyeri pasca operasi

- Hipotiroidisme

- Infeksi kronis: kandidiasis, penyakit parasit kekurangan vitamin B 12

Sindroma nyeri viscerosomatik ini diakibatkan oleh munculnya TRPS maka hal ini menunjukkan terjadinya MPS sekunder. Diagnosis MPS karena radikulopati biasanya tampak jelas ketika terdapat gangguan neurologis, ditemukan bulging atau herniasi pada diskus melalui pemeriksaan MRI, atau didapatkan hipertrofi foraminal dengan adanya root impingement. Namun, hasil pemeriksaan tersebut belum cukup untuk menentukan hubungan sebab akibat yang mendasari munculnya MPS sekunder pada radikulopati. Gangguan jaringan ikat sering telah memperberat MPS. Hal ini menunjukkan pentingnya deteksi nyeri yang dialami oleh pasien yang berasal dari MPS serta deteksi gangguan jaringan ikat yang berperan dalam memperberat MPS baik rheumatoid arthritis maupun osteoarthritis. MPS dapat diklasifikasikan menjadi sindrom nyeri regional dan sindrom nyeri general pada jaringan muskuloskeletal. Regional maupun general dapat menjadi gangguan akut dan gangguan kronis. MPS merupakan sindrom yang berarti kumpulan gejala pada jaringan otot sehingga dapat dianggap sebagai penyakit pada otot $(1,2)$.

\section{Mekanisme Perifer}

Neuron aferen somatosensori merupakan sel saraf yang selalu menerima rangsang dari lingkungan sekitar untuk mendeteksi stimulus yang membahayakan. Nosisepsi sendiri berperan pada sistem saraf somatosensori, berdasarkan fungsinya dibagi menjadi exteroseptif, proprioseptif, dan interoseptif. Fungsi exteroseptif diantaranya mechanoreception, thermoreception, dan nociception. Sedangkan fungsi proprioseptif berfungsi untuk memberikan informasi terkait posisi tubuh dan tungkai melalui reseptor pada sendi, otot, dan tendon. Interoseptif berfungsi menerima rangsang yang berasal dari dalam rongga tubuh.

Neuron sensori primer merupakan sel saraf yang berperan penting dalam proses sensori pada perifer. Neuron sensoris primer merupakan sel yang memiliki badan sel terletak pada dorsal root ganglia, dan diklasifikasikan menurut ukuran badan sel, derajat myelinasi, dan kemampuan dalam merespon factor neurotropik.

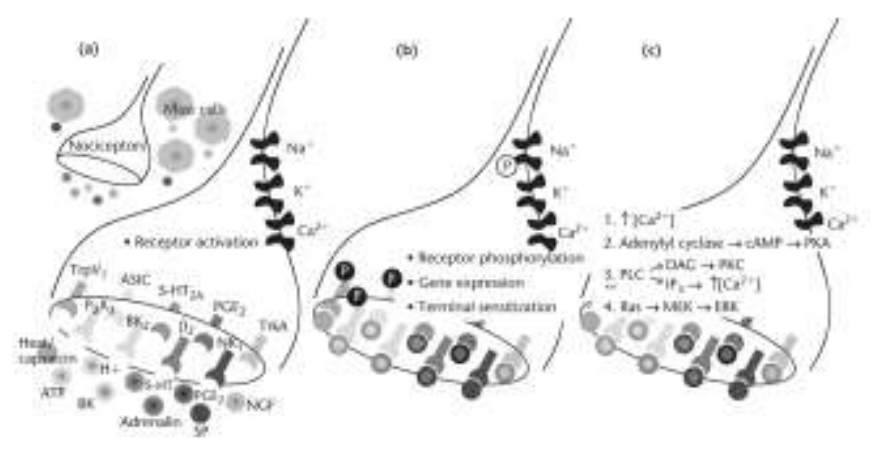

Gambar 3. Aktivasi dan Sensitisasi Nosiseptor oleh berbagai Mediator (3)

Pada korda spinalis terjadi proses transmisi yang diawali oleh pengeluaran asam amino (glutamate dan aspartate), peptide (substance $\mathrm{P}$ dan CGRP) dan faktor neurotropik (brain derived neurotropic factor (BDRF)) yang akan berfungsi sebagai neurotransmitter. Depolarisasi dari neuron terminalis primer akan menyebabkan pengeluaran glutamate yang akan mengaktivasi AMPA sehingga memberikan informasi lokasi dan intensitas dari stimulus nyeri. Sumasi dari rangsangan serabut $C$ yang berulang-ulang akan menyebabkan depolarisasi membrane post sinap yang progresif sehingga akan berujung pada aktivasi glutamate pada reseptor NMDA dan reseptor glutamate. Peningkatan aksi potensial pada kornu dorsalis yang terjadi secara terus menerus akan menyebabkan munculnya long-term potentiationLTP) yang disebabkan oleh stimulus frekuensi yang tinggi dan diikuti respon conditioningstimulus, proses inilah yang akan mempengaruhi fungsi learning dan memori pada hippocampus serta sensitisasi pada korda spinalis. Proses LTP merupakan salah satu proses yang berperan dalam munculnya sensitisasi sentral yang berujung pada hyperalgesia dan allodynia $(4,5)$.

\section{Mekanisme Sentral}

Jalur spinotalamik ascending merupakan jalur yang naik dari terminal afferent primer pada lamina I dan II melalui koneksi pada lamina $\mathrm{V}$ kornu dorsalis menuju thalamus hingga ke korteks somatosensory. Jalur ini berfungsi untuk memberikan informasi terkait nyeri yang dirasakan baik lokasi maupun jenis stimulus nyeri. Jalur spinoreticular dan spinomesencephalik merupakan jalur yang menuju medulla dan batang otak yang penting dalan integrase nosiseptif dengan kesadaran, homeostasis, dan respon autonomy yang juga mempengaruhi komponen emosional dan afektif. Jalur spinoparabrachial merupakan jalur yang berasal dari neuron kornu dorsalis lamina I superficial menuju hipotalamus ventromedial dan nucleus sentral pada amigdala. Selain jalujalur diatas masih terdapat berbagai jalur yang berperan dalam komponen afektif dari nyeri seperti anteriorcingulate cortex, insular cortex, dan prefrontal cortex. Jalur lain yang berperan dalam dalam flight or fight response serta stressinduced analgesia adalah jalur yang menuju pada periaqueductal grey (PAG) pada midbrain dan rostroventromedial medulla (RVM). Jalur yang menuju ke formation reticularis merupakan jalur yang penting dalam regulasi descending dari korda spinalis (5).

Jalur descending merupakan jalur yang berperan penting dalam modulasi transmisi nyeri pada korda spinalis melalui presinap serabut aferen, postsinap pada neuron proyeksi, atau 
melalui peran intrinsic interneuron pada kornu dorsalis. Sumber dari jalur modulasi descending tersebut dapat berasal dari corticofugal baik secara langsung maupun tidak langsung, melalui struktur modulasi seperti PAG, dari korteks dan hypothalamus. Fungsi modulasi ini penting dalam koordinasi informasi autonomic dan sensoris. RVM menerima input afferent dari batang otak, (PAG, nucleus parabrachial, dan nucleus tractus solitaries), RVM juga berperan penting dalam fungsi descending pada korda spinalis. Keseimbangan antara inhibisi descending bergantung pada intensitas stimulus nyeri dan adanya kerusakan jaringan. Jalur serotonergic dan noradrenergic pada funiculus dorsolateral juga berperan pada efek inhibisi pada transmisi nyeri. Proses transduksi, transmisi dan modulasi utama pada nyeri tampak pada gambar (5).

\section{Neurobiologi dan Patogenesis Nyeri Otot}

Sensitisasi sentral dan perifer merupakan dasar mekanisme dari munculnya MPS. Terdapat mekanisme biokimia pada terjadinya sensitisasi perifer dan sensitisasi sentral dalam munculnya nyeri otot. Aktivasi yang berlangsung terus menerus pada nosiseptor otot akan menyebabkan pelepasan substansi P dan glutamat pada terminal pre-sinaps di kornu dorsalis. Sebagai akibatnya hal ini menyebabkan pembukaan maksimal kanal ion -permeabel kalsium, yang akan menyebabkan eksitasi yang berlebihan dari neuron nociceptive dan menginduksi apoptosis dari neuron inhibisi. Selain itu, input berbahaya (noxious) yang berkepanjangan dapat menyebabkan perubahan jangka panjang dalam ekspresi gen pada neuron, mekanisme somatosensori, dan hubungan sinaptik pada korda spinalis hingga system saraf pusat. Dapat terjadi aktivasi dari sinapsis yang sebelumnya diam (silent) menjadi lebih aktif dan efektif. Mekanisme dari sensitisasi perifer dan sensitisasi sentral ini akan menurunkan ambang aktivasi saraf aferen dan terminal pusat saraf aferen yang mengakibatkan aktivasi saraf aferen bahkan dalam merespon stimulasi yang tidak berbahaya. Sebagai akibatnya, rangsangan yang tidak berbahaya seperti tekanan ringan dan gerakan otot dapat menyebabkan rasa sakit $(1,6)$.

\section{Titik Pemicu Nyeri (Myofascial Trigger Points)}

MTrPs merupakan nodul local yang keras dan dapat diraba, yang terletak di dalam serabut otot rangka. Jika dilakukan penekanan pada MTrp, maka akan dirasakan nyeri. Terdapat 2 jenis MTrPs yaitu MTrP aktif (active MTrP (A-MTrP)) dan MTrP laten (latent MTrP (L-MTrP)). A-MTrP merupakan MTrp yang berkaitan dengan terjadinya nyeri yang muncul secara spontan, nyeri yang muncul tanpa dipicu oleh palpasi. Nyeri secara spontan ini dapat terjadi pada lokasi tempat berada MTrP maupun bagian yang jauh dari lokasi MTrP. Sedangkan L-MTrP tidak berhubungan dengan nyeri spontan. Namun pemberian rangsang mekanik pada L-MTrP seperti sentuhan menggunakan jari dapat memicu rasa nyeri pada subyek pada awalnya tidak merasakan nyeri atau subyek asimtomatik. Selain itu rangsangan mekanik pada MTrP akan menimbulkan Local Twitch Response (LTR) dapat yang tampak secara visual. LTR adalah kontraksi cepat dari serat otot yang bersifat sementara dan merupakan karakteristik dari MTrPs. Pada seseorang dengan keluhan nyeri spontan, palpasi menyeluruh pada jaringan myofascial diperlukan untuk mengidentifikasi dan membedakan A-MTrP dan LMTrP. Nyeri ditimbulkan oleh palpasi dari L-MTrP pada subyek simtomatik berbeda secara kualitatif erhadap nyeri yang mberasal dari keluhan subjek. MTrP seringkali berkaitan dengan berbagai kondisi nyeri lainnya termasuk radikulopati, disfungsi sendi, patologi diskus, tendinitis, disfungsi craniomandibular, migrain, carpal tunnel syndrome, whiplash-ascociated disorder, disfungsi vertebrae, post herpetic neuralgia, dan complex regional pain syndrome $(7,8,9)$.

\section{Aspek Biokimia dan Jaringan Myofascial Trigger Points}

Hipotesis Integrated dapat dijelaskan secara biokimia. Kondisi biokimia terkait dengan hipotesis ini menunjukkan bahwa disfungsi utama pada MTrP adalah peningkatan yang abnormal pada produksi dan pelepasan asetilkolin (Ach) pada saraf motorik terminal dalam kondisi istirahat. Pelepasan asetilkolin pada kondisi istirahat akan memicu depolarisasi yang berkelanjutan. Depolarisasi yang berkelanjutan ini menyebabkan pelepasan yang terus menerus dari ion kalsium yang diikuti dengan penyerapan ion kalsium yang inadekuat dari retikulum sarkoplasma. Peningkatan ion kalsium akan menyebabkan munculnya kontraksi yang terus menerus dari sarkomer yang membutuhkan energi yang juga terus menerus meningkat. Pemendekan serabut otot yang berlangsung terus menerus akan menyebabkan kontraktur yang akan menekan pembuluh darah, mengurangi asupan nutrisi dan oksigen, sehingga menyebabkan krisis energi pada otot. Zat sensitisasi, seperti substansi P (SP) dan calcitonin gen related peptide (CGRP) yang dikeluarkan pada proses ini akan bekerja padasaraf otonom dan sensorik termasuk saraf nosiseptif, yang berada pada daerah disekitarnya. Proses ini dilanjutkan dengan proses pelepasan zat neurovasoactive seperti bradikinin, prostaglandin, histamine yang akan berperan pada proses selanjutnya yaitu pelepasanAch rilis yang berlebihan pada terminal saraf sehingga Dalam keadaan fisiologis, ATP pada membran presinaptik dari neuron motorik akan menghambat pelepasan asetilkolin (Ach). Penurunan ATP menyebabkan peningkatan pelepasan ACh sehingga terjadi kontraksi otot yang berkepanjangan. Selain itu, kurangnya jumlah ATP pada motor end plate akan mengakibatkan kegagalan pompa kalsium, sehingga terjadi peningkatan kadar $\mathrm{Ca} 2+$ pada sarkoplasma, dan hal ini akan menginduksi pelepasan $\mathrm{Ca} 2+$ dari retikulum sarkoplasma, yang selanjutnya akan memperkuat kontraksi sarkomer hingga kontraktur yang berkepanjangan (1).

Calcitonin gen related peptide (CGRP) dapat meningkatkan pelepasan ACh dari motor endplate dan secara simultan akan menurunkan efektivitas dari acetyl cholinesterase (AChE) di celah sinaps. Penurunan efektivitas AChE akan menyebabkan penurunan eliminasi AChE. Akibat dari gangguan akitivitas AChE adalah Ach yang terus menerus berada di celah sinap dan memicu kontraksi. CGRP juga berperan dalam menyebabkan upregulasi dari Ach-reseptor (AChR) pada otot. CGRP akan menyebabkan peningkatan tempat terjadinya docking antara Ach dengan AChR. Aktivitas yang terjadi pada motor endplate merupakan proses yang secara garis besar dipengaruhi oleh AChR dan konsentrasi dari Ach. Sedangkan konsntrasi Ach sendiri dipengaruhi oleh pelepasan Ach, reuptake, dan eliminasi ACh oleh AChE. Secara singkat, peningkatan konsentrasi CGRP akan menyebabkan peningkatan pelepasan Ach, sehingga meningkatkan efek dari Ach dengan cara mengurangi efektivitas AChE dan meningkatkan efisiensi AChR. Mekanisme tersebut akan meningkatkan efek yang lebih 
besar dari Ach. Pembentukan MTRPS akan memicu abnormalitas postur karena adanya nyeri. Hal ini akan menyebabkan kaitan antara postur tubuh yang buruk dan asimetris membentuk lingkaran setan bersama dengan MTRPS yang akan memperburuk terjadinya MPS $(8,10)$.

\section{KESIMPULAN}

Sindroma nyeri miofasial adalah sindroma nyeri pada otot yang termasuk pada kelainan muskuloskeletal. Patofisiologi yang berperan pada MPS adalah adanya serabut otot yang kencang dan tegang serta nyeri jika dilakukan penekanan yang disebut juga titik pemicu nyeri (MTRP). Nyeri yang muncul akibat penekanan pada MTRP juga dapat muncul dalam bentuk nyeri alih pada lokasi yang jauh terhadap MTRP. MPS dapat muncul regional atau general. MPS yang berlangsung hingga kronis, biasanya merupakan MPS general, namun MPS tidak akan berubah menjadi fibromyalgia. MPS dapat diklasifikasikan menjadi MPS primer dan sekunder. MPS primer merupakan MPS tanpa ada kelainan medis lain. MPS sekunder merupakan sindrom nyeri yang muncul akibat kondisi medis lain. Adanya MTRP dapat menjadi alat untuk mendiagnosis MPS. Namun untuk menemukan MTRP diperlukan pemeriksaan fisik yang teliti dan pemeriksaan jaringan patologi anatomi, yang sulit dilakukan pada praktek dokter sehari-hari. Analisis MTRPS lain menggunakan ultrasonografi juga masih memerlukan peninjauan lebih jauh.

\section{DAFTAR PUSTAKA}

1. Gerber N, Sikdar S, Hammond J, Shah J. A brief overview and update of myofascial pain syndrome and myofascial trigger points. J Spinal ... [Internet]. 2011;6(1):55-64. Available from: https://www.spinerf.org/sites/default/files/journal/A Brief Overview and Update of Myofascial Pain Syndrome and Myofascial Trigger Points.pdf

2. Gerwin RD. Classification, epidemiology, and natural history of myofascial pain syndrome. Curr Pain Headache
Rep [Internet]. 2001;5(5):412-20. Available from: http://dx.doi.org/10.1007/s11916-001-0052-8

3. Holdcroft A, Jaggar S. Core topics in pain [Internet]. Core Topics in Pain. Cambridge University Press; 2005. p. 1$345 . \quad$ Available from: http://dx.doi.org/10.1017/cbo9780511544583

4. Dunning J, Butts R, Mourad F, Young I, Flannagan S, Perreault T. Dry needling: a literature review with implications for clinical practice guidelines. Phys Ther Rev [Internet]. 2014 Aug [cited 2020 Feb 9];19(4):25265. Available from: http://www.ncbi.nlm.nih.gov/pubmed/25143704

5. Schug SA, Macintyre P, Power I, Scott D, Visser E, Walker $S$. The scientific evidence in acute pain management. Acute Pain [Internet]. 2005;7(4):161-5. Available from: http://dx.doi.org/10.1016/j.acpain.2005.09.006

6. Mense S. The pathogenesis of muscle pain. Vol. 7, Current Pain and Headache Reports. Current Medicine Group LLC 1; 2003. p. 419-25.

7. Van Hecke O, Torrance N, Smith BH. Chronic pain epidemiology and its clinical relevance. $\mathrm{Br} \mathrm{J}$ Anaesth [Internet]. 2013;111(1):13-8. Available from: http://dx.doi.org/10.1093/bja/aet123

8. Zhuang XQ, Tan SS, Huang QM. Understanding of myofascial trigger points. Vol. 127, Chinese Medical Journal. Chinese Medical Association; 2014. p. 4271-7.

9. Shah JP, Thaker N, Heimur J, Aredo J V., Sikdar S, Gerber L. Myofascial trigger points then and now: A historical and scientific perspective. Vol. 7, PM and R. Elsevier Inc.; 2015. p. 746-61.

10.Shah JP, Danoff J V., Desai MJ, Parikh S, Nakamura LY, Phillips TM, et al. Biochemicals Associated With Pain and Inflammation are Elevated in Sites Near to and Remote From Active Myofascial Trigger Points. Arch Phys Med Rehabil [Internet]. 2008 Jan [cited 2020 Feb 13];89(1):16-23. Available from: http://www.ncbi.nlm.nih.gov/pubmed/18164325. 